にはグリニャール試薬を生成物から除くのは大変困難である。また，本法の 場 合トリアルキルアルミニウムは，2,2'dipyridyl および生成物と反応するので不適当である。

\title{
引用文献
}

1）山本明夫, 森藤和彦, 池田朔次, 斎藤太郎, 内田安三, 御園生晃, J. Am. Chem. Soc. 874652 (1965)： ibid. 901878 (1968)

2）日本化学会編「実験化学講座」 2 基礎技術II p. 66 丸善 (1956)

\section{5-Bromosalicylic acid}

提案者 浅岡忠知, 島崎長一郎, 宮島 晃

(富山大学工学部)

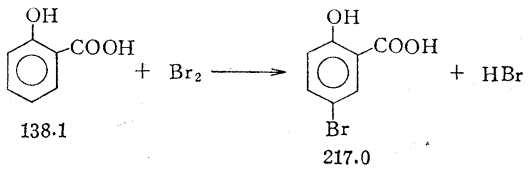

\section{I. 製法}

内容 $500 \mathrm{~m} l$ の四つロフラスコにかくはん機, 滴下漏斗, 温度計および還流冷却器を取り付け, 冷却器の上端は臭化 水素吸収装置（注意 1) にゴム管で接続しておく。四つロフラスコに salicylic acid $27.6 \mathrm{~g}(0.2 \mathrm{~mol})$, アンチモン粒 $4.0 \mathrm{~g}\left(0.003 \mathrm{~mol}\right.$ ) (注意 2 ) および四塩化炭素 $90 \mathrm{ml}$ (注意 3 ) を入れ, 温度を $70^{\circ} \mathrm{C}$ に保ち, かきまぜながら臭素 $32.0 \mathrm{~g}(0.2 \mathrm{~mol})$ を四塩化炭素 $50 \mathrm{~m} l$ に溶かした溶液を滴下漏斗から 3 時間かけて滴下寸る。加え終ってからさらに 同温で 3 時間かきまぜ続ける。放冷後, 反応混合物中の沈殿をこしわけ, $70 \sim 80^{\circ} \mathrm{C}$ (注意 4 ) の温水でよく洗浄し, 乾 燥する。このものをメタノール $200 \mathrm{~m} l$ に溶解し,アンチモン粒などを除去するため再度口過し, 口液に 70 100 $\mathrm{m} l$ の水 を加え, 室温で 1 時間内外静置した後, 生じた沈殿を吸引口過し, さらにメタノール-水系溶媒で $2 \sim 3$ 回再結晶精製す

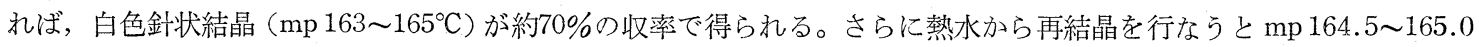
${ }^{\circ} \mathrm{C}$ の純品が約 $50 \%$ の収率で得られる。

\section{II. 注 意 事 項}

（1） 系化水素吸収装置内の吸収液は $10 \%$ 水酸化ナトリウム水溶液 $100 \mathrm{ml}$ で十分である。

（2）鉄粉が通常使用されるが，アンチモン粒 (20 mesh 以下) の方が約 $10 \%$ 収率が増大寸る。その他, 鉄粉は $5 \mathrm{~A}$ （東洋口紙）の定性口紙による吸引口過では 1 回の操作のみでは完全に除去できなく，また反応生成物は紫色に着色さ れるので製品がよごれる。

（3）四塩化炭素以外の溶媒としては，二硫化炭素 ${ }^{13}$ は応温度 $50^{\circ} \mathrm{C}$ で収率はやや多いが，引火性を考えれば有利 ではない。ベンゼンでは bromobenzene が副生し, 酢酸 ${ }^{2}$ では 3,5-dibromosalicylic acid が副生し, 溶媒としては不 適当である。

（4）洗浄温水の温度が $80^{\circ} \mathrm{C}$ 以上になると bromosalicylic acid の溶解損失がある。

\section{III. 性質}

$\mathrm{mp} \mathrm{164} 165^{\circ} \mathrm{C}$ の白色針状結晶（水から）。泠水には難溶であるが，熱水に溶ける。メタノール，エタノール，アセ トン，エーテルには易溶，クロロホルム，ベンゼンには室温では難溶であるが熱時には可溶。

\section{IV. 本法の利点}

5-bromosalicylic acid の製法としては dipotassium salicylate と次亜臭素酸カリウムとの反応 ${ }^{3,4)}$ のらな方法もあ るが，原料および操作の面からいって salicylic acid の臭素化法がもっとも実用的である。

ここに記した臭素化の条件は Heinzerling ${ }^{1}$ の報告をもとにして著者らが条件をしゅじゅ検討した結果，もっともよ かった条件を記載したものである。

\section{文献}

1) H. Heinzerling, Z. Chem. 710 (1871)

2) H.K. Silk, J. Chem. Soc. 261228 (1904) 
3) L.C. Schultze, Ber. 383294 (1905)

4) U. Kopetschni, ibid. 44428 (1911)

\section{2, 3-Benzotropone}

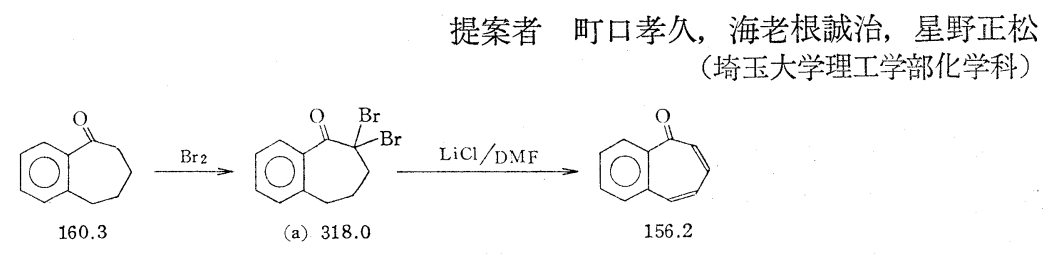

\section{I. 製 法}

$300 \mathrm{ml}$ の三つロフラスコに冷却管（注意 1 ） および滴下漏斗をつける。2,3-benzosuberone ${ }^{1)} 16 \mathrm{~g}(0.10$ モル) を乾 燥四塩化炭素 $100 \mathrm{~m} l$ に溶かし, かきまぜながら臭素 $32 \mathrm{~g}(0.20 \mathrm{~mol})$ を乾燥四塩化炭素 $50 \mathrm{~m} l$ に溶かした溶液を 滴 下する (注意 2)。滴下終了後一夜放置したのち, 反応終了液をチオ硫酸ナトリウム水溶液で洗浄し, つついて中性に なるまで水洗する。無水硫酸マグネシウムで乾燥し四塩化炭素を減圧留去すると淡黄色の 7,7-dibromo-2,3-benzosuberone (a) の粗結晶 $32 \mathrm{~g}$ を得る (注意 3 )。収率定量的。

上記（a）を無水ジメチルホルムアミド $1.0 l$ に溶解し無水塩化リチウム $20 \mathrm{~g}(0.43 \mathrm{~mol}$ ) (注意 4 ) 壳す汸やく加え 窒素気流中 2 時間加熱還流した後, 溶媒を $1 / 10$ 量残す程度に減圧濃縮する。水水約 $300 \mathrm{~g}$ を加えたのちエ一テル抽出し 水洗後無水硫酸マグネシウムで乾燥する。窒素気流中エーテルを留去し, 真空 蒸 留によりかなり純粋な淡黄色の2,3benzotropone を 13.1 14.8g (収率 84 95\%) 得る（注意 5 )。

\section{II. 注 意 事項}

（1）大量に発生する臭化水素を吸収させるため，冷却管上部に塩化カルシウム管をつけ，さらにその先端をゆるく 流した水流管につなぐ。

（2）反応は発熱して激しくなると別反応を起すので，4 時間かけてゆっくり滴下する。

（3）減圧留去するとき, 浴温 $40^{\circ} \mathrm{C}$ 以下に保たないと褐変し結晶化しない。(a) の粗結晶を一部とりペンタンで再 結晶を行ならと $\mathrm{mp} 44 \sim 45^{\circ} \mathrm{C}$ の無色柱状結晶が得られる。

(4) 塩化リチウムは $300^{\circ} \mathrm{C}$ 以上で数時間真空乾燥したものを用いる。吸湿性なのでグローブボックス中で秤量し， すばやく反応フラスコ中に加える。

（5）さらに純粋な無色油状物を得るためには，ピクラートとしクロロホルムから再結晶を繰り返したのちアルミナ カラムクロマトグラフ (10\% エタノールを含むクロロホルムで溶離)を行ない蒸留する。

\section{III. 性質}

淡黄色油状物質, bp $100.0^{\circ} \mathrm{C} / 0.01 \mathrm{mmHg}$ 。

\section{IV. 本法の利点}

従来の方法 ${ }^{2}$ は 2,3-benzosuberone から 2,3-benzotropone に至る段階が長く高価な試薬を必要とし，しかも収率 が低く単一物質の生成は困難であった。最近発表された Jones らの方法 ${ }^{32}$ は優れているが実際に実験を追試してみると 必ずしも原報に記載してあるとおりの好結果は得られなかった。上記の方法は Jones らの方法に若干の改良を加えたも のであって, 単一物質として高純度のものが収率良く得られる。

\section{引用文献}

1) R.C. Gilmore, Jr., W.J. Horton, J. Am. Chem. Soc. 731411 (1951)

2) G.L. Buchanan, D.R. Lockhart, J. Chem. Soc. 19593586

3) E.W. Collington, G. Jones, J. Chem. Soc. 19692656 